Research article

\title{
Classification of riparian woody plant communities along the Thamalakane River in northwestern Botswana
}

\author{
G. Tsheboeng ${ }^{1 *}$, D. Teketay ${ }^{2}$, M. Murray-Hudson ${ }^{3}$, K. Kashe ${ }^{3}$, M. Mmusi ${ }^{3}$ and J. Madome ${ }^{3}$ \\ ${ }^{1}$ Department of Biological Sciences, University of Eswatini, Private Bag 4, Kwaluseni, Eswatini \\ ${ }^{2}$ Department of Range and Forest Resources, Botswana University of Agriculture and Natural Resources, Private Bag 0027, \\ Gaborone, Botswana \\ ${ }^{3}$ Okavango Research Institute, University of Botswana, Private Bag 285, Maun, Botswana
}

\section{ARTICLE INFORMATION}

\section{Keywords}

Braun-Blanquet

Disturbance

Species richness

Evenness

Indicator species

\section{Article History:}

Submission date: 02 Jan. 2020

Revised: 27 Jan. 2020

Accepted: 13 Mar. 2020

Available online: 04 Apr. 2020

https://bojaas.buan.ac.bw

\section{Corresponding Author:}

G. Tsheboeng

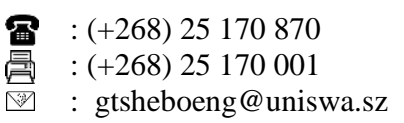

Abstract: There is still paucity of information on the species composition of woody species along the Thamalakane River, northern Botswana, which may limit efforts aimed at conserving riparian woodland species. The current study was aimed at classifying the vegetation and determining the species composition and diversity of the riparian woodland plant communities along the Thamalakane River. It was hypothesized that there will be no different woodland communities along the Thamalakane River. The 71 sampling plots measured $1000 \mathrm{~m}^{2}$ $(20 \mathrm{~m} \times 50 \mathrm{~m})$. In each plot,the percentage cover for each species was estimated following the Braun-Blanquet scale. Different woodland communities were determined through Hierarchical Cluster Analysis followed by Indicator Species Analysis. Multi-Response Permutation Procedures (MRPPs) were used to determine whether or not there was a significant separation between the groups. The Kruskal-Wallis test was used to statistically compare the diversity between woodland communities. Five major woodland communities were identified along the Thamalakane River, namely Vachellia tortilis-Gardenia volkensii, Combretum imberbe-Gymnosporia senegalensis, Philenoptera violaceaGarcinia livingstonei, Dichrostachys cinerea-Flueggea virosa and Croton megalobotrys-Colophospermum mopane. There was significant $(p<0.05)$ separation between the plant groups. Species diversity was highest in Dichrostachys cinerea-Flueggea virosa community and lowest in Vachellia tortilis-Gardenia volkensii community. The distribution of woodland species along Thamalakane river could be influenced by human disturbance, which may override abiotic environmental conditions such as flooding in influencing the composition and distribution of plant species. This calls for proper management initiatives of the riparian vegetation in the study area. Such initiatives may include establishment of exclosures to promote the germination and propagation of the woodland species. Other strategies may include education and raising awareness among local communities to promote their sustainable use of riparian vegetation.

\section{Introduction}

The human population in the Okavango Delta relies on riparian woodland vegetation for food and timber (Neelo et al. 2015; Teketay et al. 2016). Recently, it has also been shown that tourists prefer the Okavango Delta for its aesthetic value, which is promoted by the riparian vegetation (Matlhola 2016).
The woodland vegetation also indirectly promotes tourism since it serves as source of food for the browsing wild animals, such as elephants, which attract the tourists to the Okavango Delta. In the past, riparian woodland species, such as Diospyros mespiliformis Hochst.ex A.DC, Kigelia africana (Lam.) Benth, Philenoptera violacea (Klotzch) Schrire, Garcinia livingstonei T. Anderson, were 
used for dug-out canoe (mokoro) construction, which local communities use for their livelihood activities, such as fishing, hunting and transport of goods (Ecosurv 1988). Despite their importance, riparian woodland species are threatened by overexploitation, which predispose them to degradation.

Over-exploitation of woodland resources may result from excessive cutting for poles used in construction of fields, homesteads and kraals. Riparian wetland ecosystems offer land suitable for crop production, which results in deforestation due to clearing land for planting and fencing the fields (Reddy and Gale 1994). It is expected that the demand for agricultural and residential land in riparian ecosystems will increase as the human population increases. This will put more pressure on the woodland resources. Currently, there are flood recession fields used for flood recession farming, known locally as molapo farming, along the Thamalakane River where woodland species, such as Senegalia mellifera (Vahl) Seigler \& Ebinger, Vachellia tortilis Galasso \& Banfi and V. erioloba (E. Mey.) P. J. H. Hurter are used for fencing (Neelo et al. 2015). While these fields are generally on the river banks in the seasonal floodplains, they are likely to encroach in the riparian zone in response to increased flooding, which will submerge them. These threats are exacerbated by apparent lack of knowledge on the composition of riparian woodland species along the Thamalakane River.

Riparian woodland species composition has been extensively studied in other ecosystems. These include studies conducted by Medina (1986) in Mexico, Roberts and Ludwig (1991) in Australia, Lyon and Sagers (2002) in Missouri, Fousseni et al. (2011) in Togo, Strohbach (2013) in Namibia, de Oliveira et al. (2014) in the Pantanal, Brazil and Revermann et al (2017) in Angola. However, this is in stark contrast with the Okavango Delta where very few studies (Neelo et al. 2013; Neelo et al. 2015; Teketay et al. 2016; Tsheboeng et al. 2016a) have been carried out on the woodland species composition. Most of the previous studies were conducted on plant community composition and, mainly, focused on the herbaceous seasonal floodplain communities (Ellery et al. 1993; Bonyongo 1999; Bonyongo et al. 2000; Ellery and Tacheba 2003; Murray-Hudson, 2009; Tsheboeng et al. 2014). It is only recently that there were efforts to quantify the species composition of riparian woodland communities. However, such efforts were, mostly, limited to the upper regions of the Delta, excluding the distal areas, such as the Thamalakane River (Tsheboeng et al. 2016a).

The Thamalakane River is used for human settlement, which may result in the destruction of the woodland vegetation, resulting from land clearing for establishment of settlements. This destruction may hamper the ecological functioning of the woodland resources along the Thamalakane River.

Therefore, in order to make informed interventions, there is a need for information to support wise and sustainable woodland resource use. The objective of this study was, therefore, to classify the vegetation, and determine the species composition and diversity of riparian woodland plant communities along the Thamalakane River. We hypothesized that there will be no different woodland communities along the Thamalakane River.

\section{Materials and methods}

\section{Description of the study area}

The study was conducted along the Thamalakane River in the distal southeast regions of the Okavango Delta (Fig. 1).

The Thamalakane River, which passes through Maun village in Northern Botswana, is flooded from the Okavango Delta. The Delta is flooded from the Angolan highlands with a total inflow, ranging from a minimum of 6.0 to $10^{9} \mathrm{~m}^{3}$ and a maximum of 16.4 $\times 10^{9} \mathrm{~m}^{3}$ of which only $2 \%$ reaches the Thamalakane River (Gumbricht et al. 2004). Floodwater reaches the Thamalakane River around May/June having travelled 4-5 months from the upstream regions of the Delta (Ellery and McCarthy 1998). During low flooding periods, the Thamalakane River becomes dry from January to June (Masamba and Mazvimavi 2008). The local rainfall of ca. $450 \mathrm{~mm} \mathrm{year}^{-1}$ is asynchronous with flooding and occurs between November and March (Scudder et al. 1993). In terms of temperature, the Thamalakane River is characterized by a minimum monthly mean of $22{ }^{\circ} \mathrm{C}$ to $34{ }^{\circ} \mathrm{C}$ with average maximum temperature ranging between $30{ }^{\circ} \mathrm{C}$ to $32{ }^{\circ} \mathrm{C}$ (Scudder et al. 1993).

Livelihood activities along the Thamalakane River include livestock rearing and flood recession farming on the edges of the water as it recedes (Ellery and McCarthy 1998). Other livelihood activities include vegetable gardens, hotels, lodges and residential areas. These activities may negatively impact on the riparian woodland communities along the Thamalakane River.

\section{Sampling procedure}

The sampling plots measured $1000 \mathrm{~m}^{2}(20 \mathrm{~m} \times 50 \mathrm{~m})$. This is the plot size that was used in the earlier study on the quantification of woodland species composition in the upper regions of the Okavango Delta (Tsheboeng et al. 2016a). Riparian woody species were identified in randomly selected plots. The random selection of plots started from Matsaudi to Dikgatlhong junctions, which covered about $50 \mathrm{~km}$. A total of 71 plots were selected at $1 \mathrm{~km}$ 


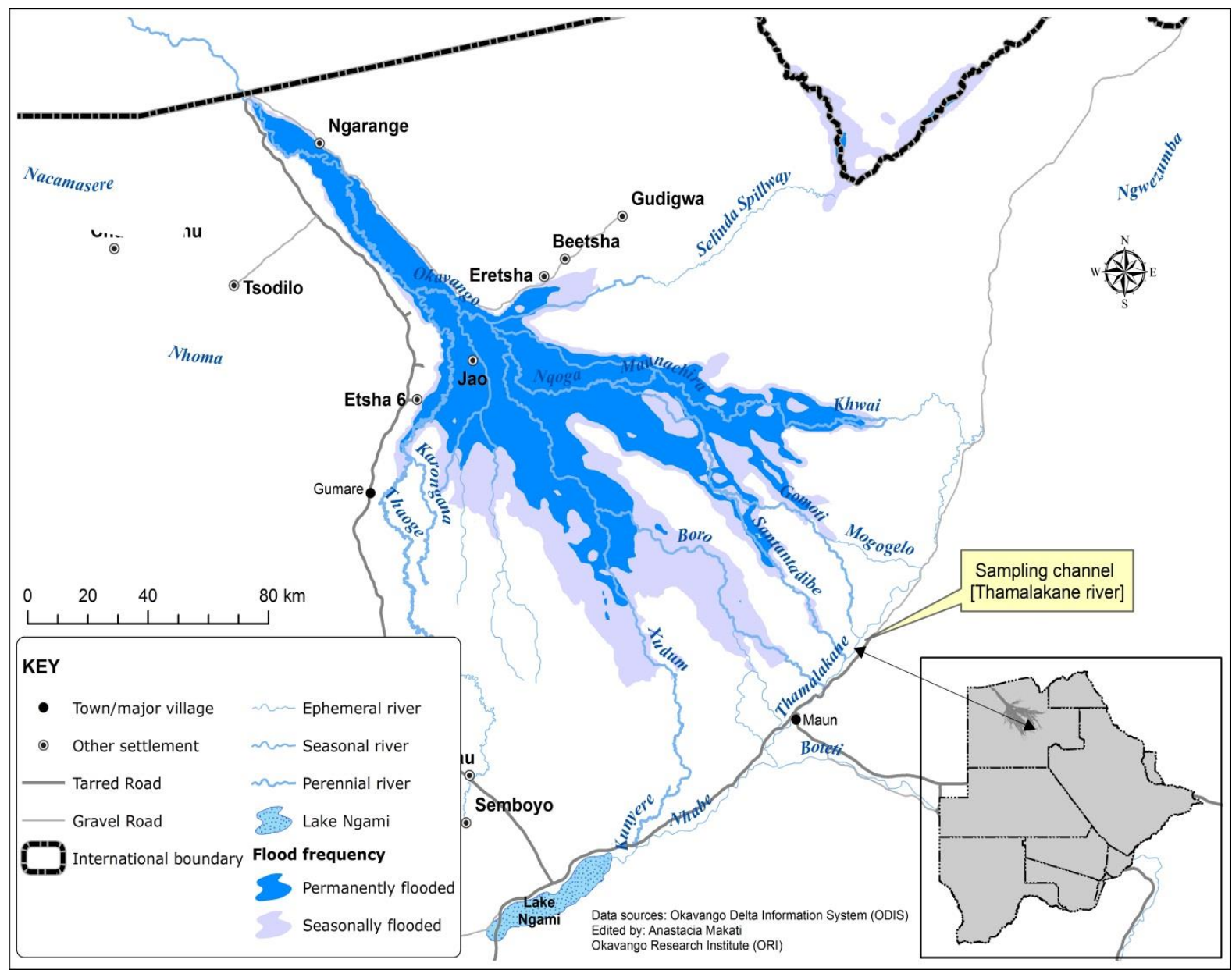

Fig. 1: Map of the Okavango Delta showing the Thamalakane River.

intervals on either side of the river with the distance measured using a GPS. Vegetation sampling was conducted during the growing season of 2015 (January-July) and 2016 (January-July). The sampling plots were placed perpendicular to the riverbank such that their short axes were closer to the water while the long axes ran into the dry reaches of the bank. In each plot percentage cover contributed by each species was estimated following the BraunBlanquet cover scale (Mueller-Dombois and Ellenberg 1974). Specimens of unknown woody species were collected, pressed, dried and identified in the Peter Smith University of Botswana Herbarium (PSUB) at the Okavango Research Institute. Plant nomenclature of the plant species included in this article follows Setshogo (2005) and Kyalangalilwa et al. (2013) (see also Table 1).

\section{Data analysis}

Different woodland communities were classified through Agglomerative Hierarchical Cluster Analysis (flexible $\beta$ linkage, $\beta=-0.25$, Sorensen distance, data relativized by maximum) in PC-ORD version 6 . This was followed by Indicator Species Analysis (ISA) (Dufrêne and Legendre 1997), which was used to determine characteristic species for each woodland community defined through cluster analysis.

Indicator species analysis was also used to determine ideal number of clusters from the vegetation data. This is where there was low mean $p$ value and high number of statistically significant indicator species (McCune and Grace 2000) given in Fig. 2. Monte Carlo testing was used to determine whether the indicator values for the species were significant. Multi Response Permutation Procedures (McCune and Grace 2000) were also used to determine whether there was a significant separation between the groups. The calculation of the MRPP gives the test statistic $T$, which is calculated as:

$$
\left.T=\left(\delta_{\text {observed }}-\delta_{\text {expected }}\right) / S D \delta_{\text {expected }}\right)
$$

where, $T=$ Test statistic, $\delta_{\text {observed }}=$ Delta observed, $\delta_{\text {expected }}=$ Delta expected and $S D=$ Standard deviation.

The $T$ statistic determines the level of separation between woodland communities in which more 


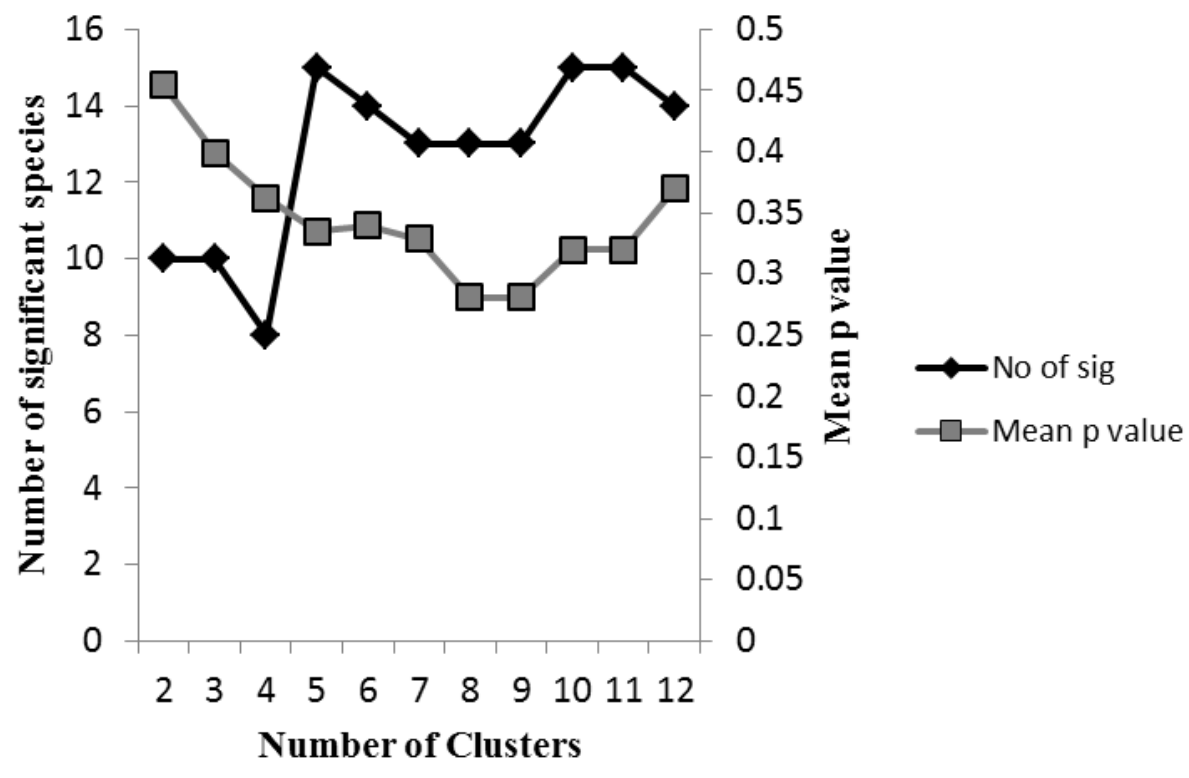

Fig. 2: Number of statistically significant indicator species and mean $p$ value of indicator species in each cluster.

negative values indicate stronger separation while less negative values show weak separation between the groups in terms of species composition.

Another output of MRPPs is the within group homogeneity, which is determined by within group agreement $A=1-\left(\delta_{\text {observed }} / \delta_{\text {expected }}\right)$.

When all the species are identical within a given group, $A_{\text {maximum }}=1$, and it is zero when heterogeneity within groups equals expectation by chance. A $<0$ when there is more heterogeneity within groups than expected by chance. In addition, species diversity, richness, evenness and density were calculated for each woodland community following the methods described by Kent and Coker (1992) and Magurran (2004).

\section{Results}

Table 1: Woodland plant community composition along the Thamalakane River.

\begin{tabular}{|c|c|c|c|c|}
\hline Species & $\begin{array}{l}\text { Indicator } \\
\text { Value }\end{array}$ & P value & $\begin{array}{l}\text { Growth } \\
\text { form }\end{array}$ & Family \\
\hline \multicolumn{5}{|c|}{ Philenoptera violacea-Garcinia livingstonei } \\
\hline Philenoptera violacea (Klotzch) Schrire & 69.6 & 0.0002 & Tree & Fabaceae \\
\hline Garcinia livingstonei $\mathrm{T}$. Anderson & 22.9 & 0.1710 & Tree & Guttiferae \\
\hline Diospyros mespiliformis Hochst. Ex A. DC. & 20.8 & 0.3065 & Tree & Ebenaceae \\
\hline Terminalia prunioides M. A. Lawson & 20.4 & 0.7743 & Tree & Combretaceae \\
\hline Vachellia luederitzii (Engl.) Kyal. \& Boatwr. & 13.3 & 0.1724 & Tree/Shrub & Fabaceae \\
\hline Maerua angolensis DC & 4.8 & 0.8508 & Tree/Shrub & Capparaceae \\
\hline \multicolumn{5}{|c|}{ Vachellia tortilis-Gardenia volkensii } \\
\hline Vachellia tortilis (Forssk) Galasso \& Banfi & 67.3 & 0.0002 & Tree/Shrub & Fabaceae \\
\hline Gardenia volkensii K. Schum & 24.8 & 0.1182 & Shrub & Rubiaceae \\
\hline Senegalia erubescens (Welw. ex Oliv.) Kyal. \& & 9.4 & 0.6253 & Tree/Shrub & Fabaceae \\
\hline
\end{tabular}

\begin{abstract}
Classification of plant communities
Agglomerative Hierarchical Cluster Analysis followed by Indicator Species Analysis (ISA) (Dufrêne and Legendre 1997), showed that there were five representative woodland communities along the Thamalakane River. The major woodland communities (named after two species with the highest indicator values) identified along the Thamalakane River were: Vachellia tortilisGardenia volkensii, Combretum imberbeGymnosporia senegalensis, Philenoptera violaceaGarcinia livingstonei, Dichrostachys cinereaFlueggea virosa and Croton megalobotrysColophospermum mopane (Table 1).
\end{abstract}


Boatwr.

Vachellia hebeclada (DC.) Kyal. \& Boatwr.

$\begin{array}{llll}6.3 & 0.8772 & \text { Tree/Shrub } & \text { Fabaceae } \\ 6.2 & 0.7510 & \text { Tree } & \text { Bignoceae } \\ 5.3 & 1.0 & \text { Tree } & \text { Anacardiaceae }\end{array}$

Markhamia zanzibarica (Bojer ex DC) K. Schum. $\quad 6.2$

Sclerocarya birrea (A. Rich.) Hochst.

inerea-Flueggea virosa

Dichrostachys cinerea-Flueggea virosa

Dichrostachys cinerea L) Wight \& Arn.

55.5

0.0004

Tree

Fabaceae

Flueggea virosa (Roxb. Ex Willd.) Voigt

49.0

0.0016

Shrub

Euphorbiaceae

Grewia bicolor A.Juss

44.8

0.0034

Shrub

Tiliaceae

Searsia tenuinervis Engl.

43.9

Shrub

Combretum mossambicense (Klotzsch) Engl.

0.0040

Shrub

Berchemia discolor (Klotzsch) Hemsl.

39.8

0.0280

Tree

Grewia retinervis Burret

35.9

0.0314

Shrub

Anacardiaceae

Combretaceae

Combretum hereroense Schinz

33.8

0.0224

Tree

Rhamnaceae

Tiliaceae

Albizia harveyi E. Fourn.

29.4

0.1172

Tree

Combretaceae

Capparis tomentosa Lam.

0.1818

Tree

Diospyros lycioides Desf

0.3422

Shrub

Ximenia americana Welw. ex Oliv.

22.0

0.0970

Shrub

Phyllanthus reticulatus Poir.

0.8362

Shrub

Euclea divinorum Hiern

20.9

0.0300

Shrub

Boscia albutrinca (Burch.) Gilg \& Gilg-Ben

0.0486

Tree

Kigelia africana (Lam.) Benth.

19.3

0.2513

Tree

Albizia anthelmintica Brongn.

10.0

0.428

Shrub

Fabaceae

Capparaceae

Ebenaceae

Olacaceae

Euphorbiaceae

Ebenaceae

Capparaceae

Bignoceae

Fabaceae

\section{Croton megalobotrys-Colophospermum mopane}

Croton megalobotrys Müll. Arg

61.9

Colophospermum mopane (J.Kirk ex Benth.) 37.1

J.Kirk ex J.Léonard

Hyphaene petersiana Mart.

Senegalia galpinii (Burtt Davy) Seigler \& Ebinger
0.0002

0.0568

Tree

Tree

0.0686 Tree

0.7355 Tree
Euphorbiaceae

Fabaceae

Arecaceae

Fabaceae

\section{Combretum imberbe-Gymnosporia senegalensis}

$\begin{array}{lllll}\text { Combretum imberbe Wawra } & 78.8 & 0.0002 & \text { Tree } & \text { Fabaceae } \\ \text { Gymnosporia senegalensis (Lam.) Loes } & 38.4 & 0.0298 & \text { Shrub } & \text { Celastraceae } \\ \text { Senegalia nigrescens } \text { (Oliv.) P.J.H. Hurter. } & 28.5 & 0.0836 & \text { Tree } & \text { Fabaceae } \\ \text { Ziziphus mucronata Willd. } & 23.3 & 0.2254 & \text { Tree } & \text { Rhamnaceae } \\ \text { Senegalia mellifera } \text { (Vahl) Seigler \& Ebinger } & 19.8 & 0.3725 & \text { Shrub } & \text { Fabaceae } \\ \text { Ficus sycomorus } \text { L } & 18.2 & 0.3011 & \text { Tree } & \text { Moraceae } \\ \text { Cordia sinensis Lam } & 16.2 & 0.1806 & \text { Shrub } & \text { Boraginaceae } \\ \text { Commiphora glandulosa } \text { Schinz } & 14.8 & 0.10008 & \text { Tree } & \text { Burseraceae } \\ \text { Combretum albopunctatum } \text { Suess } & 12.5 & 0.5845 & \text { Shrub } & \text { Combretaceae } \\ \text { Grewia villosa } \text { Willd. } & 8.0 & 0.8348 & \text { Shrub } & \text { Tiliaceae } \\ \text { Vachellia sieberiana } \text { (DC.) Kyal. \& Boatwr. } & 5.1 & 0.8670 & \text { Tree } & \text { Fabaceae } \\ \text { Vachellia nilotica } \text { (L.) P.J.H.Hurter \& Mabb } & 4.1 & 0.9228 & \text { Tree } & \text { Fabaceae }\end{array}$

\section{Description of different woodland communities}

i. Philenoptera violacea-Garcinia livingstonei community

The main indicator species in this community were Philenoptera violacea and Garcinia livingstonei
(Fig. 3). Other species found in this community were Diospyros mespiliformis, Terminalia prunioides M. A. Lawson, Vachellia luederitzii (Engl.) Kyal \& Boatwr and Maerua angolensis DC (Table 1). This is a mixture of water loving trees found at the edges of the riverbank and dry land species found at dry 


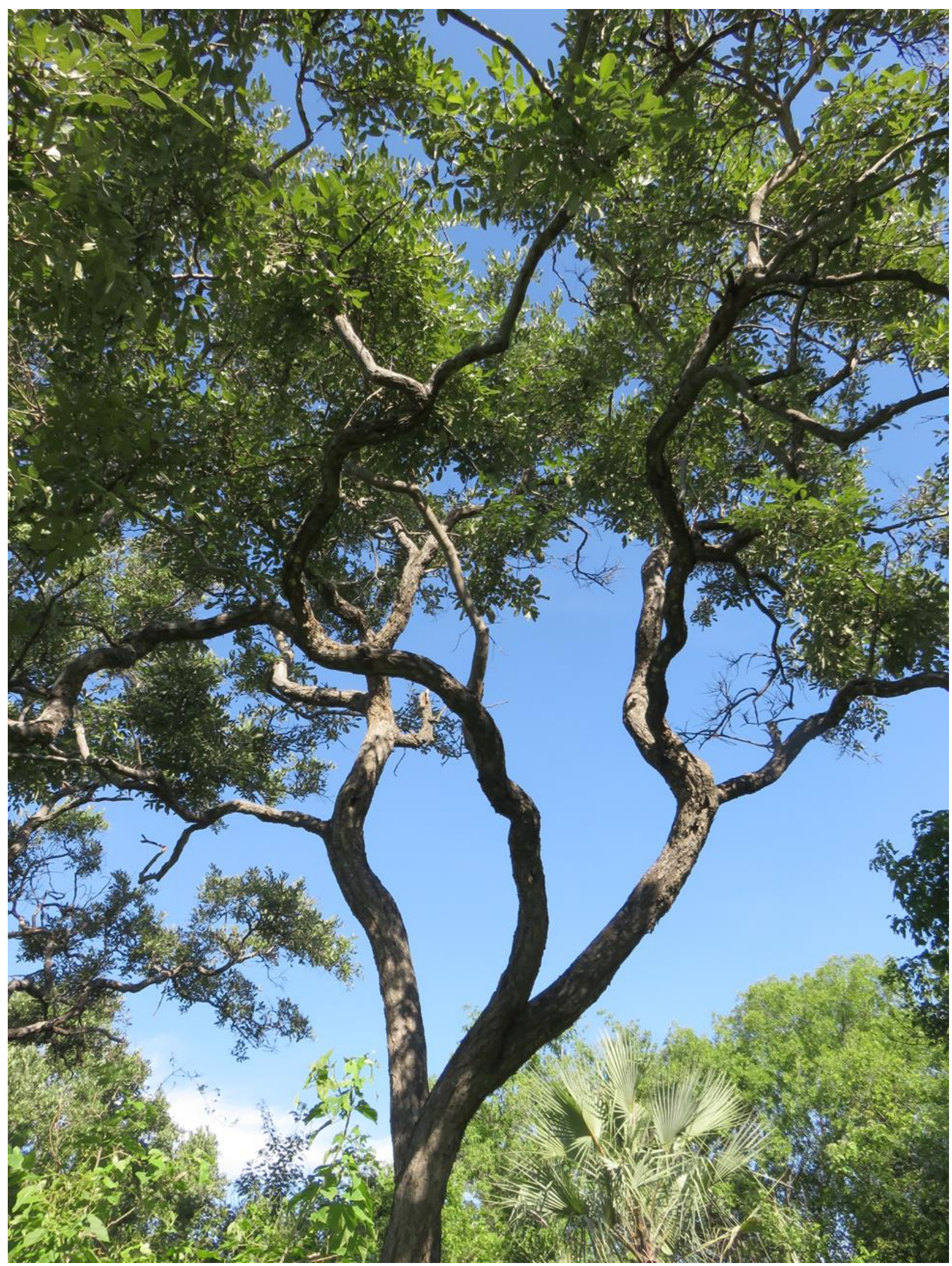

Fig. 3: Philenoptera violacea-Garcinia livingstonei community along the Thamalakane River. 
Tsheboeng et al. (2020). Bots. J. Agric. Appl. Sci. 14 (Issue 1): 47-59. ISSN 2661-9008

Table 2: Species richness, diversity $( \pm \mathrm{SE})$ and evenness $( \pm \mathrm{SE})$ in different woodland communities.

\begin{tabular}{llll}
\hline Vegetation community & Total number of species & Evenness & H' $^{\prime}$ \\
\hline PV-GL & 6 & $0.42 \pm 0.03$ & $1.45 \pm 0.11$ \\
VT-GV & 6 & $0.35 \pm 0.05$ & $0.88 \pm 0.12$ \\
DC-FV & 17 & $0.41 \pm 0.05$ & $1.78 \pm 0.19$ \\
CM-CoM & 4 & $0.24 \pm 0.01$ & $1.09 \pm 0.11$ \\
CI-GS & 12 & $0.31 \pm 0.03$ & $1.35 \pm 0.13$ \\
\hline
\end{tabular}

PV-GL (Philenoptera violacea-Garcinia livingstonei), VT-GV (Vachellia tortilis-Gardenia volkensii), DC-FV (Dichrostachys cinerea-Flueggea virosa), CM-CoM (Croton megalobotrys-Colophospermum mopane) and CIGS (Combretum imberbe-Gymnosporia senegalensis).

reaches of the riparian woodland patch. Generally, this community was found in sandy soils rich in humus. The total species number in this community was six with mean species diversity and evenness of 1.45 and 0.42 , respectively (Table 2).

ii. Vachellia tortilis-Gardenia volkensii community

The main indicator species in this community were V. tortilis and Gardenia volkensii K. Schum (Fig. 4). Other characteristic species of the $V$. tortilisGardenia volkensii community were Senegalia erubescens (Welw. ex Oliv.) Kyal \& Boatwr, Vachellia hebeclada (DC.) Kyal \& Boatwr, Markhamia zanzibarica (Bojer ex DC.) K. Schum and Sclerocarya birrea (A. Rich.) Hochst (Table 1). The Vachellia tortilis-Gardenia volkensii community is found in dryland reaches of the riparian zone. In most cases this community was found in old fields and previously disturbed sites characterized by thickets of $V$. tortilis. This community had a total of six species. The mean species diversity and evenness were 0.88 and 0.35 , respectively (Table 2).

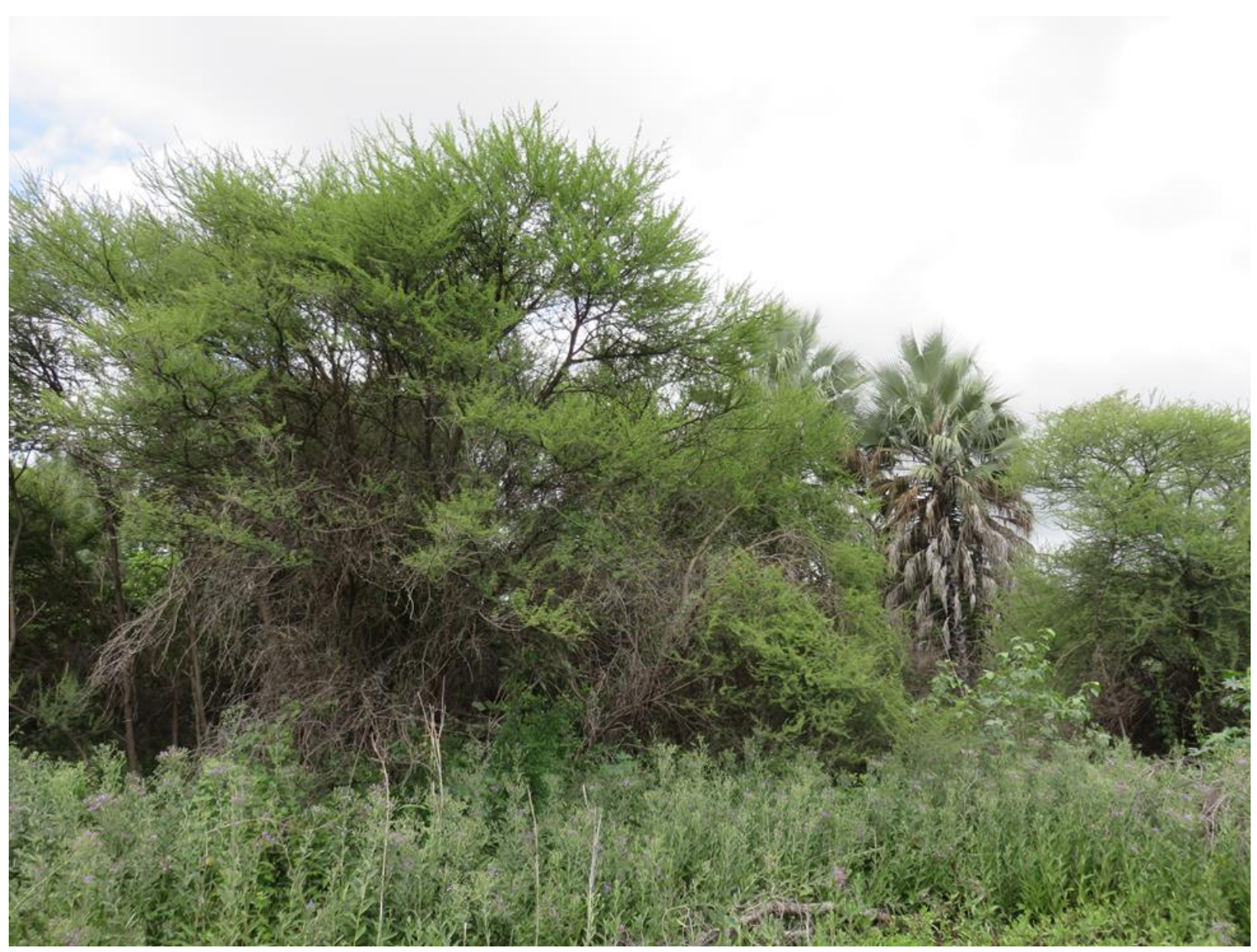

Fig. 4: Vachellia tortilis-Gardenia volkensii community along the Thamalakane River. 


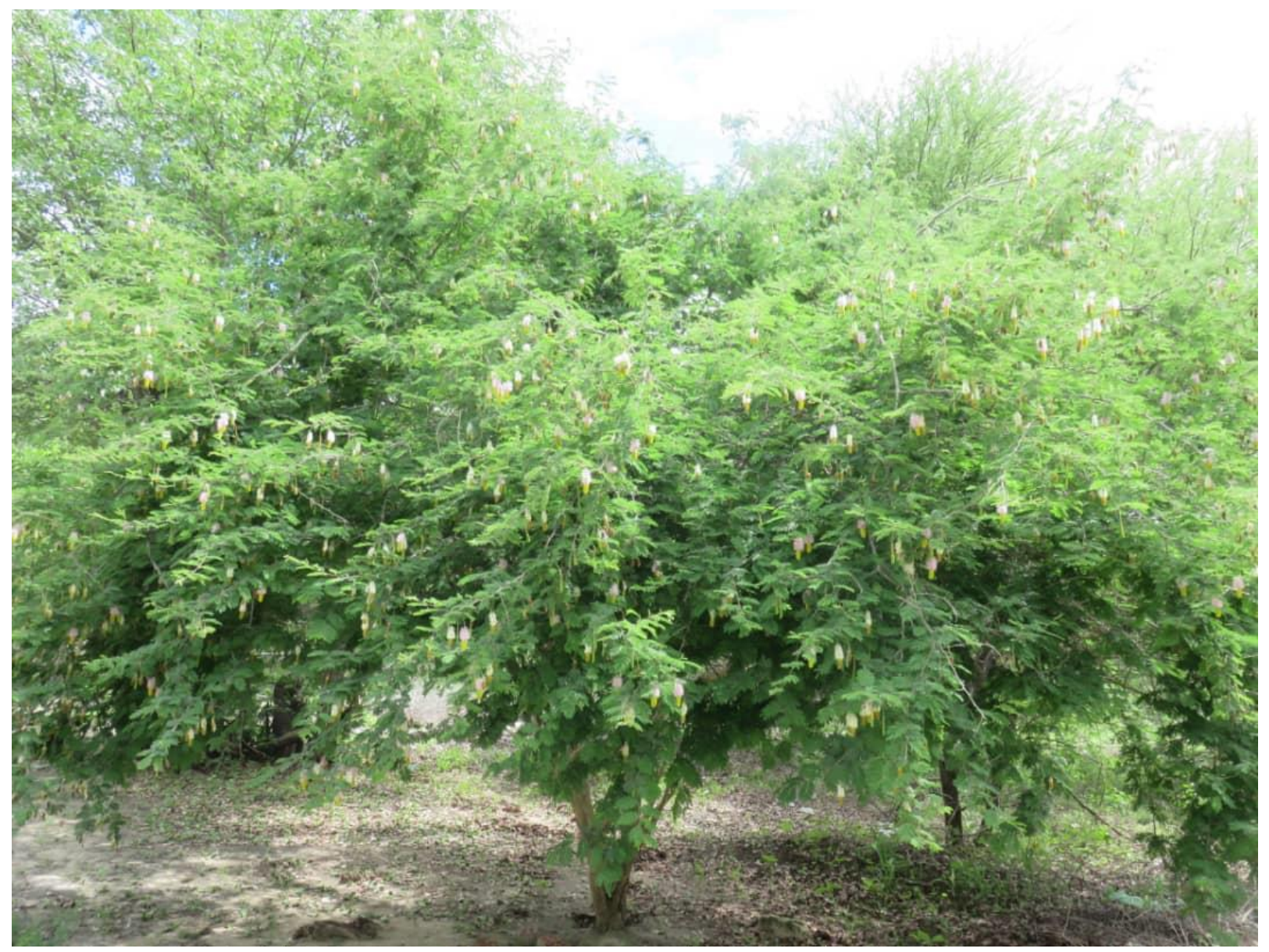

Fig. 5: Dichrostachys cinerea-Flueggea virosa community along the Thamalakane River.

\section{iii. Dichrostachys cinerea-Flueggea virosa community}

This community was characterized by thickets of $D$. cinerea (L.) Wight \& Arn and Flueggea virosa (Roxb. ex. Willd.) Voigt (Fig. 5), in old and abandoned fields in the drier reaches of the riparian zone. Species found in this community were mainly shrubs namely: Grewia bicolor A. Juss, Searsia tenuinervis (Engl.) Moffett, Combretum mossambicense (Klotzsch) Engl and a few tree species, including Albizia harveyi E. Fourn., Boscia albitruinca (Burch.) Gilg \& Benedict and Kigelia africana (Lam.) Benth (Table 1). This is a species rich community characterized by a total of 17 species. It was also the most diverse with mean species diversity of 1.78 . The mean evenness was 0.41 (Table 2).

iv. Croton megalobotrys-Colophospermum mopane community

It was characterized by Croton megalobotrys Müll. Arg and Colophospermum mopane (J.Kirk ex Benth.) J. Kirk ex J. Léonard (Fig. 6). Also,
Hyphaene petersiana Klotzsch ex Mart and Senegalia galpinii (Burtt Davy) Seigler \& Ebinger were found in this community (Table 1). The Croton megalobotrys-Colophospermum mopane community was found in both sites that were closer to the riverbank and those that were further away. It had a wide range of spatial niche with $C$. megalobotrys found in almost all the plots sampled. This community was species poor with only four species. It was also lowest in evenness and only higher than Vachellia tortilis-Gardenia volkensii community in species diversity (Table 2).

\section{v. Combretum imberbe-Gymnosporia senegalensis community}

The main characteristic species in this community were Combretum imberbe Wawra and Gymnosporia senegalensis (Lam.) Loes (Fig. 7). Other species in the Combretum imberbe-Gymnosporia senegalensis community include Senegalia nigrescens (Oliv.) P.J.H. Hurter, Ziziphus mucronata Willd, S. mellifera and Ficus sycomorus L (Table 1). This community was found in the drier margins of the riparian zone characterized by sandy soils. A total of twelve 
Tsheboeng et al. (2020). Bots. J. Agric. Appl. Sci. 14 (Issue 1): 47-59. ISSN 2661-9008

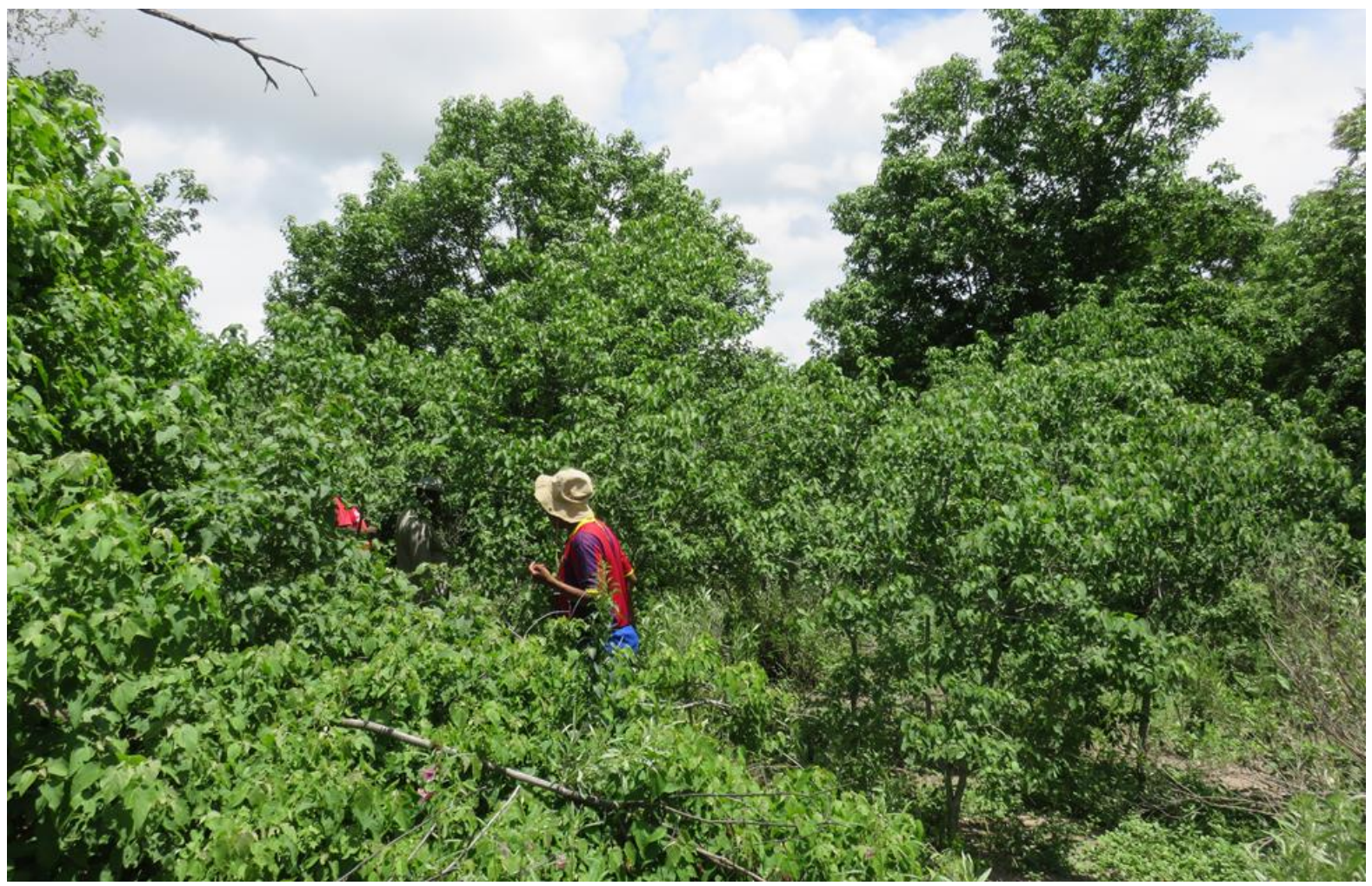

Fig. 6: Croton megalobotrys-Colophospermum community along the Thamalakane River.

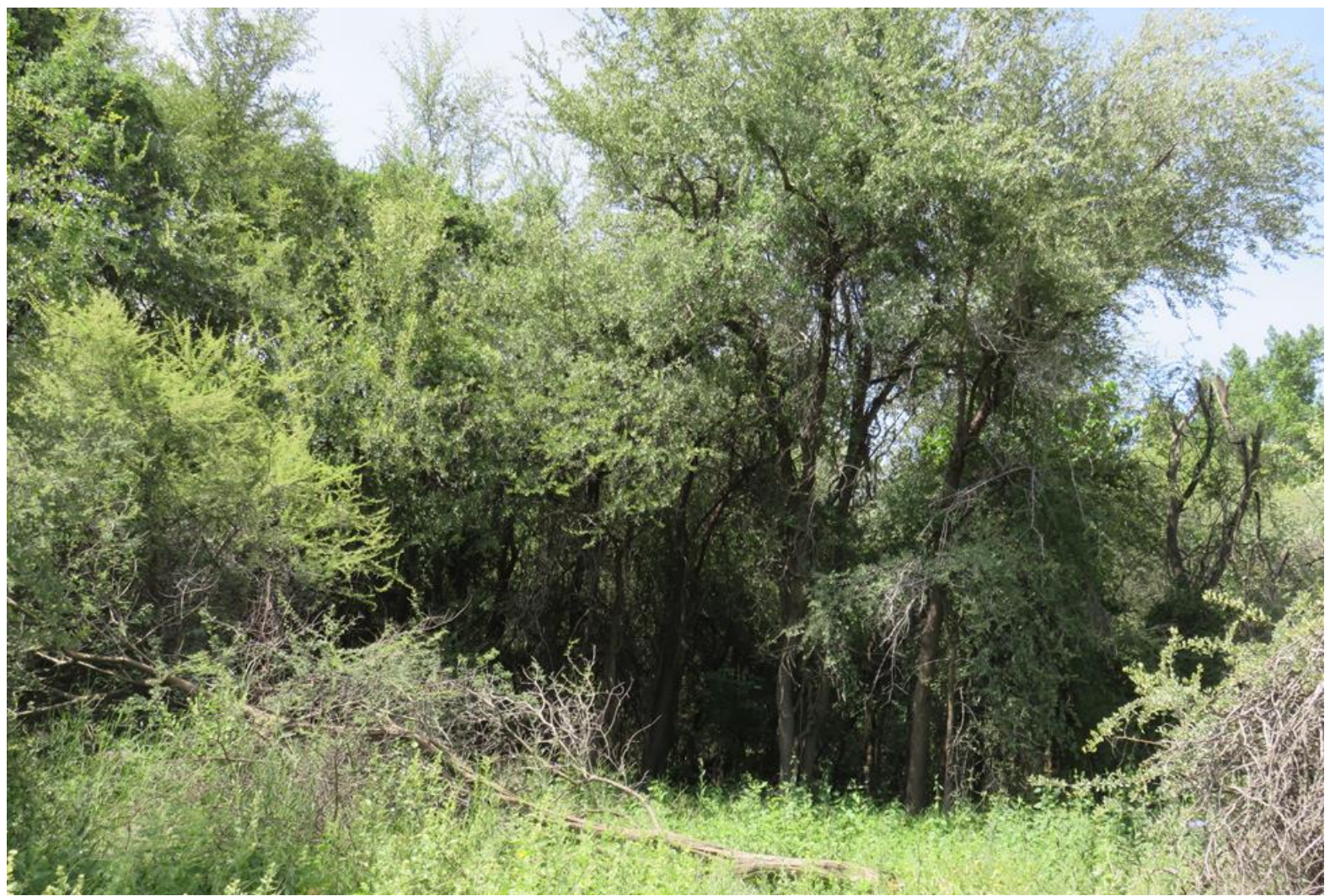

Fig. 7: Combretum imberbe-Gymnosporia senegalensis community along the Thamalakane River. 
species were identified in the Combretum imberbeGymnosporia senegalensis community with the mean species diversity and evenness of 1.35 and 0.31 , respectively (Table 2 ).

\section{Comparison of communities}

Multi-Response Permutation Procedures were used to compare plant communities along the Thamalakane river in terms of their species composition. It was found that the different communities were significantly $(p<0.05)$ different from each other in terms of plant species composition (Table 3).

Table 3: Multi-Response Permutation Procedures pairwise comparisons of woodland communities.

\begin{tabular}{|c|c|c|c|}
\hline Classes & $\mathbf{T}$ & $\mathbf{A}$ & $p$ \\
\hline PV-GL ${ }^{1}$ vs AT-GV ${ }^{2}$ & -18.00 & 0.298 & $<0.001$ \\
\hline PV-GL vs DC-FV 3 & -8.00 & 0.0890 & $<0.001$ \\
\hline PV-GL vs CM-CoM ${ }^{4}$ & -15.00 & 0.242 & $<0.001$ \\
\hline PV-GL vs CI-GS ${ }^{5}$ & -10.50 & 0.260 & $<0.001$ \\
\hline AT-GV vs CI-GS & -15.00 & 0.218 & $<0.001$ \\
\hline AT-GV vs CM-CoM & -20.52 & 0.410 & $<0.001$ \\
\hline AT-GV vs CI-GS & -12.64 & 0.309 & $<0.001$ \\
\hline DC-FV vs CM-CoM & -12.57 & 0.169 & $<0.001$ \\
\hline DC-FV vs CI-GS & -8.62 & 0.173 & $<0.001$ \\
\hline CM-CoM vs CI-GS & -12.00 & 0.351 & $<0.001$ \\
\hline
\end{tabular}

${ }^{1} \mathrm{PV}-\mathrm{GL}$ (Philenoptera violacea-Garcinia livingstonei), ${ }^{2} \mathrm{AT}-\mathrm{GV}$ (Vachellia tortilis-Gardenia volkensii), ${ }^{3} \mathrm{DC}-$ FV (Dichrostachys cinerea-Flueggea virosa), ${ }^{4} \mathrm{CM}-\mathrm{CoM}$ (Croton megalobotrys-Colophospermum mopane) and ${ }^{5}$ CI-GS (Combretum imberbe-Gymnosporia senegalensis).

\section{Discussion}

The riparian woodland vegetation along the Thamalakane River was classified into five communities: Philenoptera violacea-Garcinia livingstonei, Vachellia tortilis-Gardenia volkensii, Dichrostachys cinerea-Flueggea virosa, Croton megalobotrys-Colophospermum mopane and Combretum imberbe-Gymnosporia senegalensis.

Generally, the constituent species in the woodland communities in our study are similar to those identified by Snowy Mountains Engineering Corporation (1989) (hereafter, SMEC) in their vegetation mapping exercise in the Okavango Delta. In their study, they listed species, such as $S$. birrea, $K$. africana, $G$. livingstonei and $C$. imberbe, which were also identified along the Thamalakane River. The similarities in terms of species composition between these two studies show that the environmental conditions, which these species prefer are present in both upstream and distal regions of the Delta. However, the woodland communities identified in our study are different from Syzygium cordatum-Phoenix reclinata, Garcinia livingstoneiSenegalia nigrescens, Croton megalobotrysHyphaene petersiana and Vachellia eriolobaDiospyros lycioides that were identified in the upper regions of the Okavango Delta (Tsheboeng et al. 2016a). This difference could suggest that not all species are favoured by the prevailing environmental conditions in the distal regions of the Delta. The Syzygium cordatum-Phoenix reclinata woodland community is associated with frequent flooding conditions, which are absent in the riparian zone of the distal regions of the Okavango Delta (Tsheboeng et al. 2016b), hence, its exclusion along the Thamakalane River, which is a seasonally flooded area. Croton megalobotrys was a dominant species along the Thamalakane River and the upstream regions of the Delta. This could be an indication of its wide tolerance of moist conditions in both upstream and distal regions of the Okavango Delta. Croton megalobotrys is a pioneer species, which indicates anthropogenic disturbances, such as deforestation/vegetation clearing (Hamandawana, 2012). In Moremi Game Reserve, Hamandawana (2012) found that $C$. megalobotrys increased in abundance in response to woodland degradation by elephants.

Along the Thamalakane River, degradation of riparian vegetation mainly results from clearing land to give space for residential homes, farms and livestock kraals. The communities of Vachellia tortilis-Gardenia volkensii, Dichrostachys cinereaFlueggea virosa and Combretum imberbe- 
Gymnosporia senegalensis characterized by dryland tolerant species are indicative of the low flooding frequency conditions prevalent along the Thamalakane River. These species were $S$. erubescens, V. hebeclada, G. bicolor, Ximenia americana $\mathrm{L}, \mathrm{S}$. mellifera and Vachellia nilotica $(\underline{\mathrm{L}}$.) P.J.H. Hurter \& Mabb. The distribution of the woodland species in the distal regions of the Delta may also be influenced by human disturbance. It has been found that disturbance may override abiotic environmental conditions in influencing the species composition and distribution of plant species (Grime 1977).

The presence of Vachellia tortilis-Gardenia volkensii and Dichrostachys cinerea-Flueggea virosa communities could also indicate the human disturbance of the distal region of the Delta. The genera Senegalia and Vachellia as well as species $D$. cinerea are indicators of disturbed sites (Tolsma et al. 1987). This is because the species develop shallow rooting system, which enables them to outcompete the other species for water in the early stages of colonization (Skarpe 1990). As already mentioned previously, along the Thamalakane River, the disturbance mainly results from deforestation for building of houses, agricultural fields, making poles, firewood and road construction. Our observations during data collection showed that genera Senegalia and Vachellia and species D. cinerea were most abundant in abandoned fields, communal grazing areas and kraals. These areas are also characterized by prevalent livestock grazing. Livestock grazing has been identified as one of the threats to biodiversity (Hilton-Taylor 1996). It leads to a reduction in the plant species richness by eliminating the preferred species (Waser and Price 1981). It can also influence species composition through damage to seedlings through trampling and browsing (Fleischner 1994). In addition, livestock grazing/browsing may also influence the woodland species composition through dispersal of seeds (Strang 1974). In the Thamalakane River system, the seeds of species of Senegalia and Vachellia may be dispersed by livestock from the dry land areas into the moist micro-sites suitable for germination along the riverbank.

If the current land management system along the Thamalakane River continues where residential plots, cattle posts and farms are allocated in the riparian zone, it is likely that the disturbance to the vegetation will also prevail. The prevalence of disturbance along the Thamalakane River will compromise the ecological functioning, ecosystem services and products, which will, eventually, impact negatively on the human communities around the river. This is because the diversity of the functions will be reduced, resulting in low abundance of fruit trees, and species that provide timber and forage for animals. This calls for proper management of the woodland resources along the Thamalakane River such that the functional diversity balance is maintained. Management and conservation of the woodland resources could be achieved through proper and sustainable utilization, education and raising awareness among local communities and creation of conservancies, which will serve as refuge sites for the propagation of the woodland vegetation. The conservancies will protect the woodland plants from prolonged grazing and harvesting (Strang, 1974; San Jose and Farinas 1983; Hatton and Smart 1984; Scholes 1990; Watson and MacDonald, 2014). There should also be consideration of halting allocation of plots along the Thamalakane River while those that are already allocated plots should be encouraged to co-exist with the riparian woodland vegetation.

\section{Conclusion and recommendations}

Five plant communities of Vachellia tortilisGardenia volkensii, Combretum imberbeGymnosporia senegalensis, Philenoptera violaceaGarcinia livingstonei, Dichrostachys cinereaFlueggea virosa and Croton megalobotrysColophospermum mopane have been identified along the Thamalakane River. These communities may be a product of both abiotic and human influence. The riparian zone along the Thamalakane River is predominantly used for human settlements, which involves cutting down trees to make poles for constructing residential houses, agricultural fields and kraals. The potential response of vegetation to disturbance was shown by the presence of disturbance indicator species, such as $D$. cinerea, $V$. tortilis and $S$. mellifera. The pre-dominance of these species may indicate overgrazing in the area. This calls for proper management initiatives of the riparian vegetation in the study area. Such initiatives may include establishment of exclosures to promote germination and propagation of the woodland species. Other strategies may include education and creating awareness in the communities to promote their sustainable use of the riparian vegetation. Future studies should investigate the environmental factors that influence the composition and distribution of riparian woody plant communities along the Thamalakane River. Such studies should also quantify the extent of use of riparian woodland species by the local communities along the Thamalakane River.

\section{Acknowledgements}

The authors would like to thank Forest Conservation Botswana (FCB 00024) for providing financial support for the study with grant number FCB 00024. The authors would also like to thank the Ministry of 
Wildlife and Tourism in Botswana for granting them permission (permit number: EWT 8/36/4 XXXIV (50)) to conduct this study. We would also like to acknowledge Mr Thebe Kemosedile, Mr Charles Kabomo and the staff at Department of Wildlife and National Parks for their assistance during field data collection. The authors are also grateful to the GIS staff at the Okavango Research Institute for producing the map used in this paper and the Peter Smith University of Botswana Herbarium for helping with plant identification.

\section{References}

Bonyongo M. C. (1999). Vegetation ecology of the seasonal floodplains in the Okavango Delta, Botswana. Msc. thesis, University of Pretoria, Pretoria.

Bonyongo M. C., Bredenkemp G. J. and Veenendaal E. (2000). Floodplain vegetation in the Nxaraga Lagoon area, Okavango Delta, Botswana. South African Journal of Botany 66: 15-21.

de Oliveira M. T., Damasceno-Junior G. A., Pott A., Paranhos-Filho A. C., Suarez Y. R. and Parolin P. (2014). Regeneration of riparian forests of the Brazilian Pantanal under flood and fire influence. Forest Ecology and Management 331: 256-263.

Dufrêne M. and Legendre P. (1997). Species assemblages and indicator species: the need for a flexible asymmetrical approach. Ecological Monographs 61: 53-73.

Ecosurv. (1988). Field investigation into the mokoro industry.Kalahari Conservation Society, Gaborone, Botswana.

Ellery W. and McCarthy T. (1998). Environmental change over two decades since dredging and excavation of the lower Boro River, Okavango Delta, Botswana. Journal of Biogeography 25: 361-378.

Ellery W. N. and Tacheba B. (2003). Floristic diversity of the Okavango Delta, Botswana. A Rapid Biological Assessment of the Aquatic Ecosystems of the Okavango Delta, Botswana: High Water Survey. Bulletin of Biological Assessment 25: 69-96.

Ellery W. N., Ellery K. and McCarthy T. S. (1993). Plant distribution in Islands of the Okavango Delta, Botswana: Determinants and feedback interactions. African Journal of Ecology 31: 118-134.

Fleischner T. L. (1994). Ecological costs of livestock grazing in western North America. Conservation Biology 8: 629-644.

Fousseni F., Kperkoum W., Zhang C., Zhao X. and Koffi A. (2011). Woody vegetation of protected areas in northern Togo. Cases of Barkoissi, Galangashi and Oti-Keran: ecological and structure analyses of plant communities. Forest Studies in China 13: 23-25.

Grime J. P. (1977). Evidence for the existence of three primary strategies in plants and itsrelevance to ecological and evolutionary theory. American Naturalist 111: 1169-1194.

Gumbricht T., McCarthy J. and McCarthy T. S. (2004). Channels, wetlands and Islands in the Okavango Delta, Botswana, and their relation to hydrological and Sedimentological processes. Earth Surface Processes Landforms 29: 15-29.

Hamandawana H. (2012). The impacts of herbivory on vegetation in Moremi game reserve, Botswana: 1967-2001. Regional Environmental Change 12: 1-5.

Hatton J. C. and Smart N. O. E. (1984). The effect of long-term exclusion of large herbivores on soil nutrient status in Murchison Falls National Park, Uganda. African Journal Ecology 22: 23-30.

Hilton-Taylor C. (1996). Patterns and characteristics of the flora of the Succulent Karoo Biome, southern Africa. In: van der Maesen LJG, van der Burgt XM, van Medenbach de Rooy JM. (eds) The Biodiversity of African Plants. Springer, Dordrecht

Kent M. and Coker P. (1992). Vegetation Description and Analysis:A practical approach. Belhaven Press, London.

Kyalangalilwa B., Boatwright J. S., Daru B. H., Maurin O. and Van der Bank M. (2013). Phylogenetic position and revised classification of Acacia s.l. (Fabaceae: Mimosoideae) in Africa, including new combinations in Vachellia and Senegalia. Botanical Journal of the Linnean Society 172: 500-523.

Lyon J. and Sagers C. L. (2002). Correspondence analysis of functional groups in riparian landscape. Plant Ecology 164: 171-183.

Magurran A. E. (2004). Measuring Biological Diversity. Blackwell Publishing, Malden \& Oxford.

Masamba W. R. and Mazvimavi D. (2008). Impact on water quality of land uses along Thamalakane-Boteti River: An outlet of the Okavango Delta. Physics and Chemistry of the Earth 33: 687-694.

Matlhola D. (2016). Economic analysis of the preferences and perceptions of tourists in the Okavango Delta, Botswana: Implications for rural development. MPhil thesis, University of Botswana, Gaborone.

McCune B. and Grace J. B. (2000). Analysis of ecological communities. MjM software, Gleneden Beach, Oregon, U.S.A.

Medina A. L. (1986). Riparian plant communities of the Fort Bayard watershed in South-western New Mexico. The Southwestern Naturalist 31: 
345-359.

Muller-Dombois D. and Ellenberg H. (1974). Aims and methods of vegetation ecology. John Wiley and Sons, New York.

Murray-Hudson M. (2009). Floodplain vegetation responses to flood regime in the seasonal Okavango Delta, Botswana. PhD thesis, University of Florida, Florida.

Neelo J., Kashe K., Teketay D. and Masamba W. 2015. Ethnobotanical survey of woody plants in Shorobe and Xobe villages, Northwest Region of Botswana. Ethnobotany Research and Application 14: 367-379.

Neelo J., Teketay D., Masamba W. and Kashe K. (2013). Diversity, population structure and regeneration status of woody species in dry woodlands adjacent to molapo in Northern Botswana. Open Journal of Forestry 3:138-151.

Reddy K. R. and Gale P. M. (1994). Wetland processes and water quality: Symposium overview. Journal of Environmental Quality 23: $875-877$.

Revermann R., Gonçalves F. M., Gomes A. L. and Finckh M. (2017). Woody species of the Miombo woodlands and geoxylic grasslands of the Cusseque area, south-central Angola. Check List, the journal of biodiversity data 13: 1-10.

Roberts J. and Ludwig J. A. (1991). Riparian vegetation along current-exposure gradients in floodplain wetlands of the River Murray, Australia. Journal of Ecology 79: 117-127.

San José J. J. and Fariñas M. R. (1983). Changes in tree density and species composition in a protected Trachypogon savanna, Venezuela. Ecology 64: 447-453.

Scholes R. J. (1990). The regrowth of Colophospermum mopane following clearing. Journal of the Grassland Society of Southern Africa 7: 147-151.

Scudder T, Manley R. E., Coley R. W., Davis R. K., Green J., Howard G. W., Lawry S. W., Martz D., Rogers P. P., Taylor A. R. D., Turner S. D., White G. F. and Wright E. P. (1993). The IUCN review of the southern Okavango integrated water development project. IUCN, Gland.

Setshogo M. P. (2005). Preliminary Checklist of the Plants of Botswana. Southern African Botanical Diversity Network Report No. 37. SABONET, Pretoria and Gaborone.

Skarpe C. (1990). Shrub layer dynamics under different herbivore densities in an arid savanna, Botswana. Journal of Applied Ecology 27: 873885 .

Snowy Mountains Engineering Corporation. (1989). Ecological Zoning of Okavango Delta. Ministry of Local Government and Lands, Gaborone, Botswana.
Strang R. M. (1974). Some man-made changes in successional trends on the Rhodesian highveld. Journal of Applied Ecology 27: 249-263.

Strohbach B. J. (2013). Vegetation of the Okavango river valley in Kavango West, Namibia. Biodiversity and Ecology 5: 321-339.

Teketay D., Madome J. and Kashe K. 2016. Woody Plants along Thamalakane River in the Okavango Delta, Botswana. Lambert Academic Publishing, Saarbrüken, Germany.

Tolsma D. J, Ernst W. H. O. and Verwey R. A. (1987). Nutrients in soil and vegetation around two artificial waterpoints in eastern Botswana. Journal of Applied Ecology 24: 991-1000.

Tsheboeng G., Bonyongo M. C. and Murray-Hudson M. (2014). Influence of flood variation on seasonal floodplain vegetation communities in the Okavango Delta, Botswana. African Journal of Aquatic Science 39: 77-87.

Tsheboeng G., Murray-Hudson M. and Kashe K. (2016a). A baseline classification of riparian woodland plant communities in the Okavango Delta, Botswana. Southern Forests: Journal of Forest Science 78: 1-8.

Tsheboeng G., Murray-Hudson M. and Kashe K. (2016b). Response of riparian plant community composition to distance from surface water in the Okavango Delta, Botswana. Journal of African Ecology 55: 402-410.

Waser N. M. and Price M. V. (1981). Effects of grazing on diversity of annual plants in the Sonoran Desert. Oecologia 50: 407-411.

Watson H. K. and Macdonald I. A. W. (2014). Vegetation changes in the Hluhluwe-Umfolozi game reserve complex from 1937 to 1975. Bothalia 14: 265-269. 